\title{
Gyermekkori indolens lymphomák differenciáldiagnosztikája
}

\author{
Burján Adrienn, Nagy Dóra, Kereskai László, Kajtár Béla, Vida Livia ${ }^{\circledR}$ \\ Pécsi Tudományegyetem, Klinikai Központ, Pathologiai Intézet, Pécs
}

\begin{abstract}
Bevezetés: A gyermekkorban előforduló hematológiai megbetegedések közül az indolens non-Hodgkin-lymphomák igen ritka entitásnak számítanak. A betegség általában körülírt nyirokcsomó-megnagyobbodással jelentkezik, mely jellemzően lokalizált marad, szisztémás tünetek megjelenése nélkül, a prognózis kifejezetten kedvező. Morfológiai képük igen változatos, ami miatt gyakran differenciáldiagnosztikai kihívást jelentenek. Sajátos klinikopatológiai megjelenésük és rendkívül kedvező gyógyhajlamuk miatt a 2016-os WHO klasszifikációban önálló entitásként szerepelnek, mint gyermekkori-típusú follikuláris lymphoma és gyermekkori nodális marginális zóna lymphoma. Jelen tanulmányunk célja volt átfogó képet adni a gyermekkori indolens lymphomákról, különös hangsúlyt fektetve a differenciáldiagnosztikai problematikára. Közleményünkben részletes ismertetésre kerülnek az egyes szövettani típusok, morfológiai, immunhisztokémiai, klinikai és genetikai jellemzők szerint.
\end{abstract}

Kulcsszavak: gyermekkori indolens lymphomák, gyermekkori-típusú follikuláris lymphoma, gyermekkori nodális marginális zóna lymphoma

\section{Differential diagnostics of pediatric-type indolent lymphomas}

Introduction: Indolent non-Hodgkin lymphomas in the pediatric and young adult population are very rare. The disease usually presents as isolated, localized lymphadenopathy most often in the head and neck regions, without generalized symptoms. The histology mainly shows mature B-cell lymphoma phenotypes, distinction from reactive lymphoid hyperplasias can be often difficult. Pediatric indolent lymphomas show characteristic clinicopathological features with excellent prognosis that differ from the adult counterpart; these lymphomas can be found as a distinct entity in the 2016 WHO classification as the pediatric-type follicular lymphoma and the pediatric-type nodal marginal zone lymphoma. In this study we present the pathologic characteristics: morphology, immunophenotype and genetical features and the important differential diagnostics of these entities.

Keywords: pediatric indolent lymphomas, pediatric-type follicular lymphoma, pediatric nodal marginal zone lymphoma

(Beérkezett: 2021. június 17.; elfogadva: 2021. október 22.)

\section{Rövidítések}

AMZH - atípusos marginális zóna hiperplázia; Bcl2 - B cell lymphoma 2 protein; Bcl6 - B cell lymphoma 6 protein; EZH2 Enhancer of zeste homolog 2; FDC - Follikuláris dentritikus sejt; FISH - Fluoreszcens in situ hibridizáció; FH - Follikuláris hiperplázia; IGH - Immunglobulin nehézlánc lókusz; IRF4 - Interferon regulátor faktor 4; IRF8 - Interferon regulátor faktor 8; KMT2D - Hystone-lysine N-metilhyltransferase 2D; MAPK1 - Mitogen-activated protein kinase kinase 1; Mum1 -
Multiple myeloma 1 protein; MYC - Myelocytomatosis gén; MZL - Marginális zóna lymphoma; NHL - Non-Hodgkin-lymphoma; NMZL - Nodális marginális zóna lymphoma; PD-1 Programmed cell death protein 1; PFL - Gyermekkori-típusú follikuláris lymphoma; PNMZL - Gyermekkori nodális marginális zóna lymphoma; PTGC - Progressive transformation of germinal centers; TNFRSF14 - Tumor necrosis factor receptor super family member 14

\footnotetext{
@ Levelezési cím: Dr. Vida Livia, Pécsi Tudományegyetem, Klinikai Központ, Pathologiai Intézet, 7624 Pécs, Szigeti út 12.; Tel.: +36-30-313-9729; E-mail: vida.livia@pte.hu
} 


\section{Bevezetés}

$\mathrm{Az}$ indolens lymphomák közé tartozó betegségek a mai napig kihívást jelentő betegségcsoportot képviselnek a non-Hodgkin-lymphomák (NHL) között. Szinte kizárólag felnőttkorban fordulnak elő, az eddig megismert patogenezisük alapján egy lassan növekvő neoplasztikus lymphoid-sejtes klónnak tekinthetők. A gyermekkorban elöforduló NHL-ek sokban különböznek a felnőttkori formáktól; mind incidenciájuk, mind biológiai viselkedésük eltérő, emellett kezelésük és prognózisuk is jelentős különbségeket mutat.

A gyermekkori hematológiai malignitások közül a leggyakoribb lymphomát a klasszikus Hodgkin-lymphoma képviseli, ezt követik az NHL-ek, melyek közül az agreszszív B-sejtes lymphomák - Burkitt-lymphoma és diffúz nagy B-sejtes lymphoma (DLBCL) - fordulnak elő a leggyakrabban [1]. Az indolens B-sejtes lymphomák ebben az életkorban kifejezetten ritkák, és markáns különbségeket mutatnak a felnőttkori típusokhoz képest. A gyermekkori indolens lymphomának két típusa ismert: a gyermekkori-típusú follikuláris lymphoma (PFL) és a gyermekkori nodális marginális zóna lymphoma (PNMZL), melyek fel- nőttkori variánsaikhoz képest sokkal ritkábbak, csupán néhány százalékban fordulnak elő $[2,3]$. Továbbá gyermekkorban elöfordulhat még krónikus lymphocitás leukémia is (CLL), mely extrém ritkaságnak számít az irodalmi adatok alapján. A legutóbbi WHO-ban ezeken felül önálló entitásként jelent meg az IRF4/MUM1 átrendeződéssel járó nagy B-sejtes lymphoma is, mely ugyancsak megjelenhet a fiatal populációban a Waldeyer-gyürüben; ez azonban nagy B-sejtes morfológiája miatt a gyermekkori indolens lymphomák tekintetében differenciáldiagnosztikai problémát nem okoz. A gyermekkori lymphomák nemcsak gyermekkorban, de serdülő- és fiatal felnőttkorban is kialakulhatnak, számos tanulmányban számolnak be felnőttkorban jelentkező gyermekkori típusú indolens lymphoma esetekről $[4,5]$. A gyermekkori indolens lymphomák felismerése és a pontos diagnózis felállítása kulcsfontosságú, ugyanis ezekben az esetekben terápia nélkül is teljes gyógyulás várható, így az intenzív kemoterápia okozta terhelés és a mellékhatások is elkerülhetők. A cikkünkben részletesen tárgyalt két gyermekkori lymphomatípus - PFL és PNMZL - a 2016-os WHO klasszifikációban önálló entitásként szerepel [6].

1. táblázat. Gyermekkori indolens lymphomák leggyakoribb differenciáldiagnosztikai aspektusai

\begin{tabular}{|c|c|c|c|c|c|}
\hline & $\mathrm{FH}$ & PTGC & PFL & $\mathrm{AMZH}$ & PNMZL \\
\hline $\begin{array}{l}\text { Érintett nyirok- } \\
\text { csomók száma }\end{array}$ & egy vagy több & egy & egy & egy & egy vagy több \\
\hline Érintett populáció & $\begin{array}{l}\text { gyerekek, fiatal } \\
\text { felnőttek }\end{array}$ & $\begin{array}{l}\text { gyerekek, fiatal } \\
\text { felnőttek }\end{array}$ & $\begin{array}{l}\text { gyerekek, fiatal } \\
\text { felnőttek }\end{array}$ & $\begin{array}{l}\text { gyerekek, fiatal } \\
\text { felnőttek }\end{array}$ & $\begin{array}{l}\text { gyerekek, fiatal } \\
\text { felnőttek }\end{array}$ \\
\hline $\begin{array}{l}\text { Nyirokcsomó } \\
\text { architektúra }\end{array}$ & follikuláris expanzió & $\begin{array}{l}\text { irreguláris } \\
\text { follikuláris expanzió } \\
\text { nodulusokkal }\end{array}$ & $\begin{array}{l}\text { follikuláris } \\
\text { szaporulat }\end{array}$ & $\begin{array}{l}\text { expanzív } \\
\text { interfollikuláris } \\
\text { szaporulat }\end{array}$ & $\begin{array}{l}\text { expanzív } \\
\text { interfollikuláris } \\
\text { szaporulat }\end{array}$ \\
\hline Infiltrátum & $\begin{array}{l}\text { centrociták, } \\
\text { centroblasztok, } \\
\text { „tingible body” } \\
\text { makrofágok, T } \\
\text { sejtek és follikuláris } \\
\text { dendritikus sejtek }\end{array}$ & $\begin{array}{l}\text { kis lymphocyták } \\
\text { centrocitoid } \\
\text { sejtekkel keveredve, } \\
\text { perifollikuláris } \\
\text { epiteloid sejtek }\end{array}$ & $\begin{array}{l}\text { közepes méretü, } \\
\text { centroblaszt } \\
\text { jellegű sejtek és } \\
\text { centrocitoid sejtek, } \\
\text { „tingible body” } \\
\text { makrofágok }\end{array}$ & $\begin{array}{l}\text { bő citoplazmájú } \\
\text { középnagy sejtek: } \\
\text { monocitoid sejtek, } \\
\text { centrocitoid sejtek }\end{array}$ & $\begin{array}{l}\text { középnagy } \\
\text { monocitoid, } \\
\text { centrocitoid sejtek, } \\
\text { plazmasejtek, kevés } \\
\text { blaszt }\end{array}$ \\
\hline $\begin{array}{l}\text { Karakterisztikus } \\
\text { eltérés } 1 .\end{array}$ & $\begin{array}{l}\text { nagy, irreguláris } \\
\text { centrum } \\
\text { germinativumok, } \\
\text { T sejtek a világos } \\
\text { zónában }\end{array}$ & $\begin{array}{l}\text { makronodulusok } \\
\text { FH hátterében }\end{array}$ & $\begin{array}{l}\text { a nyirokcsomó } \\
\text { szélén ép } \\
\text { nyirokcsomó } \\
\text { struktúra („node in } \\
\text { node”) }\end{array}$ & $\begin{array}{l}\text { vagy } \\
\text { hiperplasztikus, } \\
\text { vagy atrofizált } \\
\text { centrum } \\
\text { germinativumok, } \\
\text { PTGC nem } \\
\text { jellemző }\end{array}$ & $\begin{array}{l}\text { follikuláris expanzió } \\
\text { (PTGC) jellemzi, } \\
\text { de a follikulusok } \\
\text { kolonizáltak }\end{array}$ \\
\hline $\begin{array}{l}\text { Karakterisztikus } \\
\text { eltérés } 2 .\end{array}$ & $\begin{array}{l}\text { az interfollikuláris } \\
\text { területben } \\
\text { monocitoid B-sejtes } \\
\text { hiperplázia is } \\
\text { kísérheti }\end{array}$ & $\begin{array}{l}\text { kis lymphocyták } \\
\text { által kolonizált } \\
\text { zilált centrum } \\
\text { germinativumok }\end{array}$ & $\begin{array}{l}\text { polarizációt } \\
\text { vesztett centrum } \\
\text { germinativumok, } \\
\text { a helper T sejtek } \\
\text { kiszorulnak }\end{array}$ & $\begin{array}{l}\text { lambda könnyülánc } \\
\text { restrikció } \\
\text { előfordulhat }\end{array}$ & $\begin{array}{l}\text { IgD+ fragmentált, } \\
\text { irreguláris } \\
\text { köpenyzóna }\end{array}$ \\
\hline
\end{tabular}


1. táblázat. (folyt.)

\begin{tabular}{llllll}
\hline & \multicolumn{1}{c}{ FH } & \multicolumn{1}{c}{ PTGC } & \multicolumn{1}{c}{ PFL } & AMZH & PNMZL \\
\hline $\begin{array}{l}\text { Follikulusok } \\
\text { helyzete }\end{array}$ & $\begin{array}{l}\text { monoton, bőséges } \\
\text { torlódó follikulusok }\end{array}$ & $\begin{array}{l}\text { monoton, bőséges } \\
\text { számú follikulus, } \\
\text { köztük nagy } \\
\text { nodulusok }\end{array}$ & $\begin{array}{l}\text { egymásra torlódó } \\
\text { follikulusok, nincs } \\
\text { interfollikuláris } \\
\text { populáció }\end{array}$ & $\begin{array}{l}\text { a follikulusok } \\
\text { egymástól távol } \\
\text { esnek, bőséges } \\
\text { interfollikuláris } \\
\text { populáció }\end{array}$ & $\begin{array}{l}\text { a follikulusok } \\
\text { egymástól távol } \\
\text { esnek }\end{array}$ \\
\hline IHC & bcl2-, CD20+, & $\begin{array}{l}\text { IgM+, IgD+, bcl2-, } \\
\text { CD20+, bcl6+, } \\
\text { CD10+ }\end{array}$ & $\begin{array}{l}\text { CD20+, CD79a+, } \\
\text { PAX5+, BCL6+, } \\
\text { Ki67 30\%, } \\
\text { CD10+, bcl2- }\end{array}$ & $\begin{array}{l}\text { CD20+, CD43+, } \\
\text { IgM+, IgD-, bcl2+ }\end{array}$ & $\begin{array}{l}\text { CD20+/CD43+ } \\
\text { koexpresszió, IgM+ }\end{array}$ \\
\hline
\end{tabular}

\section{A gyermekkori-típusú follikuláris lymphoma}

\section{Általános jellemzők}

A follikuláris lymphoma (FL) a nyirokcsomó germinális centrum B-sejtjeinek fenotípusát mutató, generalizált betegség, melyet kisebb centrocitoid és nagyobb centroblasztszerü lymphoid sejtek által felépített, follikuláris mintázatot mutató infiltrátum jellemez. A gyermekkoritípusú FL jellemzően lokalizált formában manifesztálódik. Habár az FL világszerte a második leggyakoribb felnőttkori NHL-típus, gyermekkori előfordulása ritka, a PFL kevesebb mint 3\%-át teszi ki az összes gyermekkori NHL esetnek [2]. A PFL-re jellemző átlagéletkor 14 év, azonban 3 éves kortól egészen a fiatal felnőttkorig bármely életkorban manifesztálódhat [7]. Nemek tekintetében főleg férfi dominancia jellemző, akár 10-szer gyakoribb lehet fiúkban, illetve fiatal férfiakban, mint nőkben $(\mathrm{M}: \mathrm{F}=10: 1)$. A betegség izolált nyirokcsomó-megnagyobbodás formájában jelentkezik leggyakrabban a fejnyak régióban, azonban előfordulhat más lokalizációban is, többet között a tonsillákban, a herékben, mellékherékben vagy a gasztrointesztinális traktusban $[2,3,7]$.

\section{Morfológiai leírás}

A PFL-t jelentős architekturális heterogenitás jellemzi, ami miatt a szövettani diagnózis felállítása igen sok nehézségbe ütközik. Általánosságban elmondható, hogy a lymphomás infiltrátum follikuláris mintázatot mutat, és többnyire középnagy centroblasztoid sejtekből áll. Gyakoriak a változó, olykor nagy méretű, néhol egymással konfluáló, vagy expanzív növekedési mintázatot mutató nyiroktüszők, melyeket általában abnormálisan keskeny köpenyzóna vesz körül. Ugyanakkor sok esetben a fiziológiásan is jelen lévő „csillagos égbolt” mintázat és a „tingible body” (vagy babzsák) makrofágok jelenléte is megfigyelhető, ami jól működő apoptotikus aktivitásra utal. Ezen jellemzői miatt igen hasonló a megjelenése a follikuláris hiperpláziához (FH) [3, 7, 8]. Előfordul, hogy a betegség a nyirokcsomón belül lokalizáltan mint körülírt folyamat jelentkezik, a neoplasztikus nyiroktüszőket körülvevő ép struktúra, úgynevezett „node in node”, vagyis nyirokcsomó a nyirokcsomóban benyomását kelti a vizsgálóban [3]. Az infiltrátumot alkotó centrocitoid és kis méretű centroblasztoid sejtek között sokszor nehéz különbséget tenni, ami a gradálást is megnehezítheti, a grádusuk általában magas. A PFL eltérő lokalizációjától függően szintén lehetnek különbségek a szövettani jellemzőikben, ami tovább árnyalja a morfológiai spektrumot $[2-4,7]$.

\section{Immunhisztokémia}

A betegség immunfenotípusát a felnőttkori FL-hez hasonlóan erős CD20 pozitivitás, valamint CD10, illetve Bcl6 expresszió egyaránt jellemzi, ami a klonális sejtek germinális centrum eredetét támasztja alá. Az interfollikuláris régiókban nem jellemző a jelentős mennyiségü CD20+ B-sejt; ez utóbbi jelenség a PNMZL-től való elkülönítését segítheti. Az esetek 24\%-ában CD43 pozitivitás is megfigyelhető, ami marginális zóna lymphomában - beleértve a PNMZL-t -, illetve a DLBCL-ek kb. $20-40 \%$-ában is jelen van, azonban a felnőttkori FL-ben extrém ritka, kevesebb mint az esetek $6 \%$-ában található meg [9]. Az MUM1/IRF4 fehérje expressziója az esetek körülbelül 20\%-ában fordul elő. Az elvékonyodott köpenyzónák azonosításában az IgD expresszió vizsgálata segít; ez a marker a neoplasztikus sejteken nem fejeződik ki [8].

A legjelentősebb különbség a felnőttkori FL-hez képest a BCL2 expressziójának a hiánya. Az ehhez kapcsolódó immunglobulin nehézlánc gént ( $I G H)$ érintő $I G H / B C L 2$ transzlokáció, mely a BCL2 fehérje konstitutív expreszsziójáért felelős, szintén nem jellemző a PFL-ben, pedig a felnőttkori FL esetek akár 90\%-ában is megtalálható [6]. A sejtproliferációt jelző Ki-67 expresszió PFL-ben jellemzően magas, értéke sokszor a $40 \%$-ot is meghaladja, sőt akár a 95\%-os pozitivitást is elérheti, ami leginkább az agresszív lymphomákra jellemző tulajdonság [4]. Mindezen különbségek tehát a PFL eltérő molekuláris patogenezisére utalnak. 


\section{Genetikai jellemzök}

Mivel a PFL a neoplasztikus B-sejtek klonális proliferációjának eredménye, az esetek klonális $I G H$ génátrendeződést mutatnak. Az IGH gén transzlokációi, beleértve a BCL2, BCL6, MYC vagy IRF4 géneket, PFL-ben nem jellemzők, ahogyan a $B C L 2$ gént érintő amplifikáció sem fordul elő [8]. A klasszikus felnőttkori follikuláris lymphomában igen gyakori epigenetikai módosulásokért felelős gének mutációi - EZH2, CREBBP, KMT2D - is csak ritkán, felnőttkori PFL esetekben fordulnak elő [10].

Néhány gyermekkori indolens lymphomát jellemző abnormalitás ismert az irodalomban: 6p24.3 amplifikáció (ami fokozott IRF4/Mum1 expresszióért lehet felelős), valamint 1 p36 deléció fordul elő. Az utóbbi társulhat TNFSRF14 mutációval, ami az esetek 54\%-ában megtalálható, de felnőttkori FL-ben is leírt eltérésnek számít [3, $12,13]$.

\section{Klinikai jellemzök}

A PFL kórlefolyása a felnőttkori FL-lel ellentétben igen kedvező, az 5 éves túlélése $95 \%$ feletti. Fontos különbséget jelent, hogy amíg a felnőttkori FL sokszor disszeminált, előrehaladott stádiumban kerül felismerésre, addig a PFL jellemzően lokalizált, alacsony stádiumú betegség és nagyon kedvező gyógyhajlammal bír. Még a magasabb stádium, illetve szövettani grádusuk sem befolyásolja érdemben a prognózist. Éppen ezért elegendőnek bizonyul az érintett nyirokcsomó diagnosztikus céllal elvégzett sebészi kimetszése és az ezt követő szoros kontroll [2, 3, 8].

\section{IFR4 átrendezödéssel járó nagy B-sejtes lymphoma}

A legutóbbi WHO klasszifikációban önálló entitásként leírt nagy B-sejtes lymphoma IRF4-átrendeződéssel több szempontból is átfedést mutathat a PFL-lel [6]. A betegség jellemzően gyermekkorban, illetve fiatal felnőttkorban (medián életkor 12 év) jelentkezik a fej-nyak régióban, különösképpen a tonsillákban, sokszor lokalizált folyamatként. Gyakran diffúz, de olykor kevert, diffúz és follikuláris vagy tisztán follikuláris mintázat látható a szövettani vizsgálat során, melyet középnagy, illetve nagy méretü sejtek alkotnak. Follikuláris mintázat esetében egymásra torlódó tüszőket látni, a csillagos égbolt rajzolat nem jellemző. A sejtek CD10, Bcl6 és CD20 pozitivitás mellett erős, homogén MUM1 expressziót mutatnak, a proliferációs frakció jellemzően magas, a $80-90 \%$-ot is elérheti [3]. A diagnózis alapja az IRF4 átrendeződés kimutatása molekuláris módszerekkel, a transzlokációs partner jellemzően az IGH gén. Kemo- és/vagy radioterápia mellett a kórlefolyás kedvező, de a biológiai viselkedés eltér a PFL-től, ezért a PFL nem igényel szisztémás kezelést $[3,7,8]$.

\section{A gyermekkori nodális marginális zóna lymphoma}

\section{Általános jellemzők}

A marginális zóna lymphomák (MZL) a felnőttkori NHL-ek körülbelül 10\%-át teszik ki, mellyel a harmadik leggyakoribb B-sejtes lymphomának számítanak a DLBCL és az FL után [12]. A WHO klasszifikáció három nagy csoportot különít el: az extranodális, a szplenikus, illetve a nodális MZL (NMZL) típusokat, természetesen a PNMZL is ez utóbbi csoporthoz tartozik [6]. Amíg felnőttkorban az extranodális MZL fordul elő gyakrabban, addig a gyermekkori MZL inkább nodális típusú. Az NMZL az összes MZL-nek mindössze 10\%-át teszi ki, tehát összességében az NHL-ek kevesebb mint 2\%-át alkotja, gyermekkori variánsa pedig még ennél is ritkább entitásnak számít. A PNMZL-es betegek átlagéletkora 16 év, azonban a kisgyermekkortól egészen a fiatal felnőttkorig előfordulhat. Habár a PNMZL-t elsőként az immundeficiens vagy HIV-pozitív gyermekekben figyelték meg, hamar leírásra kerültek olyan esetek is, ahol ezen említett tényezők nem játszottak szerepet a betegség kialakulásában $[2,16]$. A PNMZL lokalizációját tekintve a PFL-hez hasonlóan a fej-nyak régióban alakul ki; a nyaki nyirokcsomó érintettség a leggyakoribb $[2,3,5]$.

\section{Morfológiai leírás}

A PNMZL szövettani megjelenése is változatos. A felnőttkori NMZL-re jellemző mintázatok - diffúz, noduláris/follikuláris, interfollikuláris és perifollikuláris mindegyike elöfordulhat PNMZL eseteiben is $[17,18]$. PNMZL-ben egyarán jellemzők a monocitoid és a centrocita karakterű lymphoid sejtek, melyek diffúzan infiltrálják a nyiroktüszőket körülvevő interfollicularis zónát, elszórtan plazmasejtek és nagyobb, blaszt-karakterü sejtek - centroblasztok, immunoblasztok, ritkán plazmocitoid sejtek - is megtalálhatók. Ritkán az érintett nyirokcsomóban follikuláris hiperplázia is látható a germinális centrumok progresszív transzformációjával (PTGC) [8, 19, 20].

\section{Immunhisztokémia}

A PNMZL immunfenotípusa sokban hasonlít a felnőttkori NMZL-re, tehát nincs jellemző, sajátos immunfenotípusbeli megjelenése. A neoplasztikus sejteket erős CD20 pozitivitás, valamint CD43-expresszió jellemzi. A BCL2 fehérje expressziója az esetek körülbelül felében jelen lehet. A germinális centrum markerek közül mind a BCL6, mind a CD10 negatívak. A PNMZL esetek körülbelül 21\%-ában IgD pozitivitás is megtalálható, amely a neoplasztikus nyirokcsomóban előforduló PTGC-struktúrákat is jól kirajzolja. Az interfollikuláris terekben lévő neoplasztikus sejteket általában alacsony sejtproliferáció és Ki-67 expresszió jellemzi. Egyéb mar- 

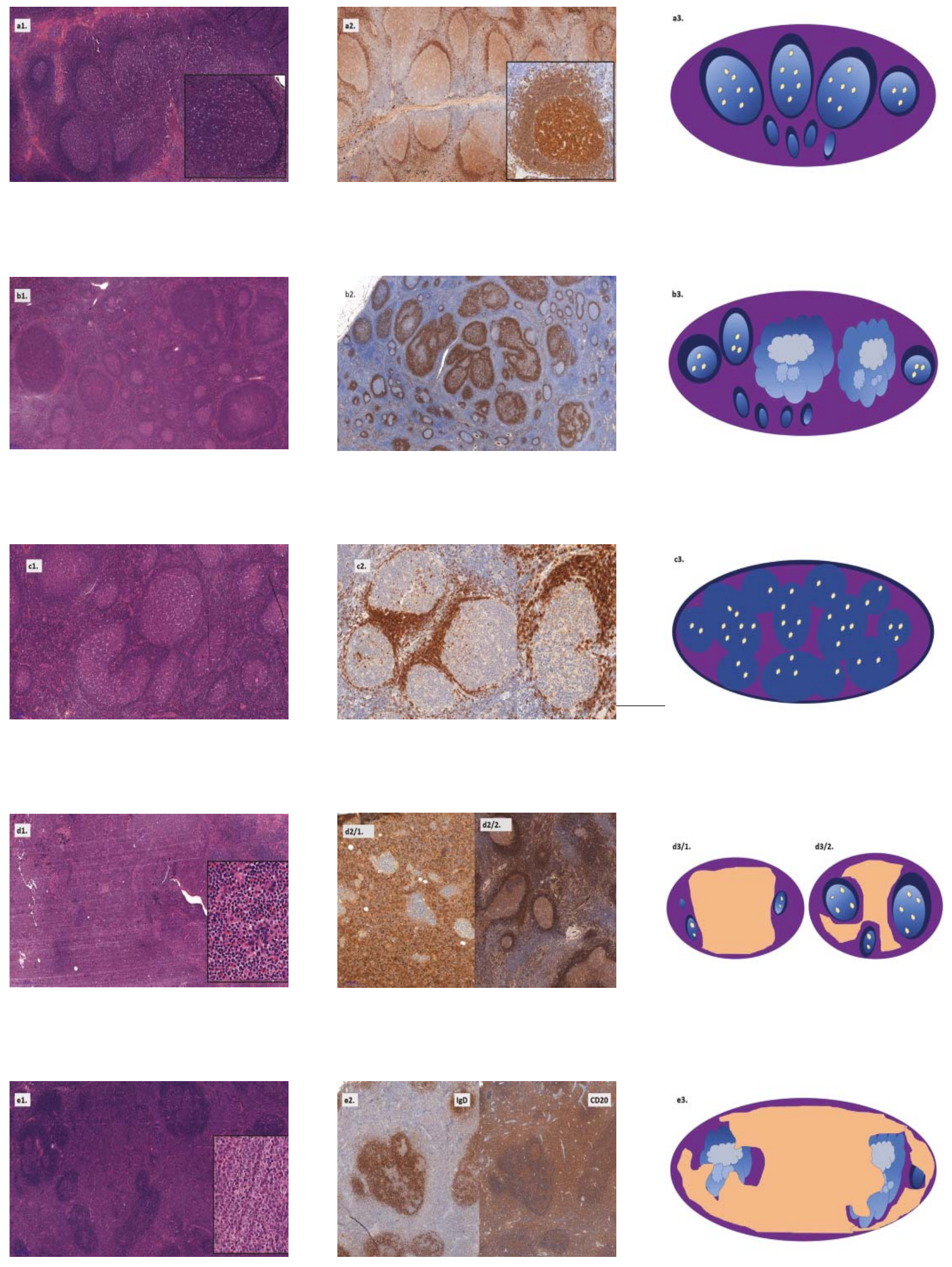

1. ábra. Gyermek és fiatal felnőtt reaktív és neoplasztikus nyirokcsomó-elváltozások jellegzetes szövettani tulajdonságai, valamint a nyirokcsomók szerkezete 


\section{Ábrajegyzék az 1. ábrához}

\section{a: Follikuláris hiperplázia (FH)}

a1: a nyirokcsomó masszív follikuláris expanziót mutat, a centrum germinativumokban (CG) „tingible body” makrofágok

jelenlétével. Az inzertben: CG zonációval és „csillagos égbolt” rajzolattal, hematoxilin-eozin (HE)

a2: expanzív CG sejtpopuláció, IgD jelölés; az inzertben CD20 jelölés

a3: szerkezeti sajátosságok: nagy méretű CG-k, zonáció, „csillagos égbolt” rajzolat

\section{b: A centrum germinativumok progresszív transzformációja (PTGC)}

b1: irreguláris follikuláris expanzió nagy progresszív nodulusokkal, HE

b2: irreguláris, felbomló köpenyzónák és CG maradványok, IgD jelölés

b3: szerkezeti sajátosságok: irreguláris noduláris formák zilált CG maradványok, háttérben FH

\section{c: Gyermekkori follikuláris lymphoma (PFL)}

c1: egymásra torlódó follikulusok keskeny köpenyzónával; inzert: „node in node”, „,csillagos égbolt”, HE

c2: szabálytalan méretű torlódó follikulusok; IgD jelölés a szabálytalan köpenyzónákat hangsúlyozza

c3: szerkezeti sajátosságok: torlódó follikulusok, polarizációt vesztett CG-k, „csillagos égbolt”

\section{d: Atípusos marginális zóna hiperplázia (AMZH)}

d1: az interfollikuláris sejtszaporulat széttolja az atrófiás follikulusokat, a minta extranodális lokalizációból, az appendixből származik; inzert: bő citoplazmájú monocitoid, centrocitoid sejtek, HE

d2/1: atrófiás follikulusok jelenléte, IgD jelölés; $\mathrm{d} 2 / 2$ : $\mathrm{AMZH}+\mathrm{FH}$, IgD jelölés

d3/1: szerkezeti sajátosságok atrofizált follikulusok, interfollikuláris sejtszaporulat; d3/2: az expandáló marginális zóna körülfolyja a hiperplasztikus follikulusokat

e: Gyermekkori nodalis marginális zóna lymphoma (PNMZL)

e1: interfollikuláris szaporulat PTGC hátterében; inzert: középnagy mono- és centrocitoid sejtek, HE

e2: interfollikuláris lymphoma infiltrátum, kolonizált PTGC morfológiájú follikulusokkal, IgD és CD20 jelölés

e3: szerkezeti sajátosságok: interfollikuláris expanzió, mely a transzformált follikulusokra is kiterjed

kerek közül, a CD5, a CD23, a MUM1 és a cyclin D1 is negatívak. A CD23, illetve CD21 markerek az FDC hálózat kimutatásában segítenek, melyet gyakran aberráns, szakadozott mintázat jellemez $[2,3,8,17]$.

\section{Genetikai jellemzők}

Az esetek kb. 20\%-ában mutatható ki valamilyen citogenetikai eltérés, melyek közül a 18-as kromoszóma triszómiája a leggyakoribb, ez az esetek kb. 20\%-ában fordul elő. Egyéb citogenetikai eltérések közül a 3-as és a 13-as kromoszómák triszómiája került leírásra jóval kisebb arányban [21]. A PFL-hez hasonlóan az IGH gént érintő transzlokációk; $M Y C, B C L 2, B C L 6$, illetve IRF4 gének transzlokációi nem fordulnak elő, jelenlétük kizárja $\mathrm{PN}$ MZL diagnózisát [8, 21].

\section{Klinikai jellemzók}

A PNMZL-t - hasonlóan a PFL-hez - kiváló prognózis jellemzi, leggyakrabban lokalizált, alacsony stádiumú a betegség. Az érintett nyirokcsomó eltávolítása után a rendszeres követés - „watch and wait” - rendszerint elegendő, szisztémás kezelés nélkül is kevés az esély a betegség kiújulására $[3,8]$.

\section{Differenciáldiagnózis}

A gyermekkori lymphomák megkülönböztetése a felnőttkori lymphomáktól alapvető fontosságú, hiszen eltérő biológiai viselkedésű és ezért eltérő kezelést igénylő folyamatokról van szó. A morfológia alapján a gyermekkori lymphomák elsősorban a reaktív nyirokcsomó elváltozásokhoz hasonlítanak. A szülők, illetve a beteg aggodalma nyilvánvalóan érthető ilyen helyzetben, a részletes szövettani feldolgozás pedig elengedhetetlenül szükséges, ezért ezek a nyirokcsomók - általában a gyermek teljes jólléti állapotában - eltávolításra kerülnek.

\section{Follikuláris hiperplázia}

A gyermekkorban jelentkező nyirokcsomó-megnagyobbodások hátterében elsősorban reaktív elváltozások fordulnak elő, melyek közül az egyik leggyakoribb entitást a reaktív follikuláris hiperplázia $(\mathrm{FH})$ képviseli. Ez az elváltozás morfológiai szempontból számos hasonlóságot mutat PFL-hez. Mindkettőt csillagos égbolt mintázat („tingible body” makrofágok jelenléte) és nagy méretü, hiperplasztikus follikulusok jellemzik, azonban a bizarr, szabálytalan alakú, polarizációjukat vesztett nyiroktüszők, illetve az abnormálisan keskeny köpenyzónák és a furcsa, 
közepes méretű, monoton, blaszt-karakterű sejtek elsősorban PFL sajátságai [8]. Az immunmarkerek közül PD-1 fehérje expressziója is segíthet az elkülönítésben, ugyanis PFL-ben a PD-1 pozitív helper T-sejtek leginkább a nyiroktüszőn kívül helyezkednek el, míg a reaktív elváltozásokban $\mathrm{PD}-1$ pozitív lymphocyták a follikulusok világos zónájában koncentrálódnak [7, 8].

\section{Atípusos marginális zóna hiperplázia}

$\mathrm{Az}$ atípusos marginális zóna hiperplázia (AMZH) egy olyan reaktív nyirokcsomó-elváltozás, amely mind klinikai, mind morfológiai szempontból hasonlít a PNMZL-hez. Lokalizált limfadenomegáliaként jelenik meg, melyet szövettanilag vagy hiperpláziás vagy atrofizált follikulusok és prominens, kiszélesedett marginális zónák jellemeznek. AMZH nemcsak a nyirokcsomóban, de akár extranodálisan is megjelenhet, például a Waldeyer-gyürüben, a tonsillákban vagy az appendixben; ezen extranodális lokalizációkban a „molyrágta” nyiroktüszők PTGC-re emlékeztető megjelenése is jellegzetes adalék lehet [22]. Egyes tanulmányok szerint AMZH gyakran Haemophilus influenzae infekció mellett alakul ki, és a betegek infekciójának célzott kezelése során spontán regrediál a folyamat [23]. A diagnózis szempontjából a molekuláris genetikai vizsgálatok is segíthetnek, mivel AMZH esetében monoklonalitás nem jellemző [8]. Egyes szerzők tanulmányaikban beszámolnak olyan AMZH esetekről, ahol az immunhisztokémiai vizsgálatok kapcsán CD43 pozitivitás és egy esetben még lambda-könnyưlánc restrikció is igazolódott, azonban genetikai vizsgálatokkal monoklonalitás nem volt kimutatható $[2,3,22]$. Mindezen tényezők rávilágítanak a gyermekkori indolens lymphomák komplexitására, hiszen számos esetben mind a morfológia, mind az immunfenotípus megfelelhet a lymphoma „kritériumainak”, azonban a legtöbbször csupán egyszerű reaktív nyirokcsomó elváltozások állnak a háttérben, ezért a molekuláris vizsgálatok elvégzése döntő fontosságú lehet.

\section{A germinális centrumok progresszív transzformációja}

A germinális centrumok progresszív transzformációja (PTGC) egy benignus elváltozás, ami általában szoliter, aszimptomatikus nyirokcsomó-megnagyobbodásként jelentkezik, leggyakrabban fiatalokat, illetve gyermekeket érint. Főleg nyaki vagy axilláris nyirokcsomóban alakul ki, florid variánsa pedig a második évtizedben lévő fiatal férfiakra a legjellemzőbb [19]. Morfológiáját tekintve a PTGC által érintett nyiroktüszők kiszélesedettek, nodulusokat formálnak a nyirokszöveten belül, és sokkal nagyobbak lehetnek a PTGC hátterében előforduló hiperplasztikus follikulusoknál. A megváltozott szerkezetü nyiroktüszőket általában a kis lymphocytákhoz hasonló megjelenésű B-sejtek infiltrálják, melyek elszórtan vagy akár tömegesen involválják a nyiroktüszőt, megváltoztatva a morfológiájukat. A sejtekre erős IgM-, illetve IgDpozitivitás jellemző. A PTGC által érintett nyiroktüszőkben CD21 reakció kapcsán szakadozott FDC-hálózat látható, illetve elszórtan centroblasztok, a follikulusok körül pedig epitelioid sejtek is előfordulhatnak. A PTGC megjelenését leggyakrabban a reaktív nyirokcsomó-elváltozásokban írták le, fóleg follikuláris hiperplázia mellett; egyes tanulmányok szerint autoimmun mechanizmusokhoz társul, azonban a pontos patogenezise és jelentősége egyelőre ismeretlen [24, 25]. A PTGC neoplasztikus folyamatokban is leírásra került, többek között a noduláris lymphocita predomináns Hodgkin-lymphomában. Ennek kapcsán egyes szerzők lehetséges preneoplasztikus léziónak tartják, mások szerint azonban csupán egy morfológiai szempontból hasonló reaktív elváltozásról van szó $[24,26]$. További tanulmányok az NMZL kialakulásával is összefüggésbe hozták mint lehetséges prekurzor léziót: Taddesse és munkatársai az általuk vizsgált PNMZL esetek 66\%-ában azonosítottak PTGC-t, azonban tényleges összefüggést nem sikerült kimutatniuk a két entitás között [19]. Érdekesség, hogy a Shaikh és munkatársai által készített tanulmányban a PTGC-vel diagnosztizált gyermekeknél fokozott FDG (fluorodezoxiglükóz) halmozás volt kimutatható az érintett nyirokcsomóban a PET-CTvizsgálatok kapcsán, ami leginkább a neoplasztikus folyamatok sajátsága [26]. Egyelőre tehát nem világos, hogyan függ össze PTGC a gyermekkori indolens lymphomákkal. Lehetséges, hogy csupán extrém reaktív morfológiai entitásról van szó, de akár az is lehet, hogy egy valódi prekurzor léziót azonosítunk, amit érdemes lesz nyomon követni a későbbiek során.

\section{PFL és PNMZL}

A két gyermekkori-típusú lymphoma egymástól való elkülönítése is számos diagnosztikus nehézséget jelent, köszönhetően a heterogén, olykor egymással átfedő morfológiai megjelenésük miatt. A PNMZL follikuláris kolonizációval is járhat, ami jellegzetes noduláris növekedési mintázattal jellemezhető, illetve marginális zóna differenciációt mutató PFL esetekre is találunk példát a szakirodalomban, de akár más lymphomatípus (pl. köpenysejtes lymphoma) lehetősége is felmerülhet a morfológia alapján. A PNMZL megjelenési mintázata általában jellegzetesebb, gyakoriak a B-sejtek által kiszélesített interfollikuláris terek és a PTGC-morfológiájú nyiroktüszők, melyek PFL esetében hiányoznak. A sejtek citológiai megjelenése is segíthet elkülöníteni a két entitást, mivel PNMZL-ben polimorf sejttársaság jellemző: monocitoid B-sejtek, centrocitoid-, illetve plazmasejtek és blasztkarakterü sejtek egyaránt megtalálhatók. A PFL-ben „back to back”, azaz szorosan egymáshoz préselt follikulusok figyelhetők meg „node in node” megjelenéssel, és inkább monomorf sejtpopuláció dominál, melyet leginkább közepes, fóleg blaszt-karakterű sejtek alkotnak. A differenciál diagnózisban az immunmarkerek is segíte- 
nek, melyek közül a germinális centrum markerek, CD10, illetve BCL6 PFL-ben mutatnak pozitivitást, míg a PD-1 pozitív sejtek aránya a neoplasztikus follikulusokban csökkent, és leginkább perifériásan helyezkednek el. Ezzel szemben PNMZL-ben a neoplasztikus sejtek CD10 és BCL6 negativitása mellett a reziduális follikulusokban intenzív PD-1 pozitív sejttársaság jelenléte nyújthat segítséget $[3,7,8]$.

\section{Összefoglalás}

A két ismertetett gyermekkori indolens lymphomának PFL és PNMZL - több közös vonása is van, mindkét entitás leginkább fiatal fiúkban, illetve férfiakban fordul elő és leggyakrabban a fej-nyak régió nyirokcsomóiban jelentkezik. Szinte mindig lokalizált, alacsony stádiumú betegségek, jellemzően egy, esetleg néhány nyirokcsomót érintenek. A prognózisuk rendkívül jó; az érintett nyirokcsomó sebészi kimetszése, majd a páciensek nyomon követése mellett a betegség kiújulásának esélye elenyésző, így a potenciálisan mellékhatásokkal járó kemo- vagy radioterápia nem szükséges. Az entitások ismerete és megkülönböztetése a felnőttkori indolens lymphomáktól éppen ezért rendkívül fontos [3, 9, 25].

A felnőttkorban kialakuló gyermekkori-típusú indolens lymphomák kapcsán, részben az alacsony esetszámuk miatt, egyelőre nincs általános, elfogadott nézőpont arra vonatkozóan, hogy a magasabb életkorban hasonlóan kedvező biológiai viselkedés és kórlefolyás várható, mint a gyermekkorban manifesztálódó eseteknél. Azonban az eddigi tapasztalatok alapján ezek is kiváló prognózissal jellemezhetők, a sebészi kimetszésen túl, akár kiegészítő terápia alkalmazása nélkül, a betegek szoros kontrollja mellett megfelelően kezelhetők [4, 5].

Patomorfológiai szempontból fontos hangsúlyozni, hogy a felnőttkori indolens lymphomák kevésbé heterogének, mint gyermekkori variánsaik. Utóbbiak kapcsán nemcsak a szövettani változatosság, a magasabb grádusuk és a reaktív kórképekhez való hasonlóságuk okozzák a legtöbb nehézséget, hanem immunfenotípus és genetikai szempontból is fontos különbségeket mutatnak.

A molekuláris biológia fejlődésével és az újgenerációs szekvenálás elterjedésével talán sikerül fényt deríteni a gyermekkori indolens lymphomák genetikai hátterére, ami segíthet megérteni kialakulásuk pontos okát és a felnőttkori formáiktól eltérő patogenezisük és klinikai lefolyásuk hátterében zajló folyamatokat.

Nyilatkozat: Kijelentem, hogy a közlemény más folyóiratban nem jelent meg és nem került máshová beküldésre. A közlemény egy része előadás formájában a 2019-es Pécsi MHTT konferencián bemutatásra került. A szerzői útmutatót elolvastam és tudomásul vettem. A kézirat végleges szövegét valamennyi szerző olvasta és jóváhagyta. Érdekeltségek: A szerzőknek nincsenek érdekeltségeik.
Szerzői munkamegosztás: A kéziratot BA, és ND és VL írta, a táblázatot és az ábrákat VL készítette, $\mathrm{KB}$ és $\mathrm{KL}$ lektorálta a kéziratot.

\section{Irodalom}

[1] Burkhardt B, Oschlies I, Klapper W, et al. Non-Hodgkin's lymphoma in adolescents: experiences in 378 adolescent NHL patients treated according to pediatric NHL-BFM protocols. Leukemia 2011; 25: 153-160.

[2] Swerdlow SH. Pediatric follicular lymphomas, marginal zone lymphomas, and marginal zone hyperplasia. Am J Clin Pathol. 2004; 122: 98-109.

[3] Quintanilla-Martinez L, Sander B, Chan JKC, et al. Indolent lymphomas in the pediatric population: follicular lymphoma, IRF4/ MUM1+ lymphoma, nodal marginal zone lymphoma and chronic lymphocytic leukemia. Virchows Arch. 2016; 468: 141-157.

[4] Louissaint A, Ackerman AM, Dias-Santagata D, et al. Pediatric-type nodal follicular lymphoma: An indolent clonal proliferation in children and adults with high proliferation index and no BCL2 rearrangement. Blood 2012; 120: 2395-2404.

[5] Gitelson E, Al-Saleem T, Robu V, et al. Pediatric nodal marginal zone lymphoma may develop in the adult population. Leuk Lymphoma 2010; 51: 89-94.

[6] Swerdlow SH, Campo E, Pileri SA, et al. The 2016 revision of the World Health Organization classification of lymphoid neoplasms. Blood 2016; 127: 2375-2390.

[7] Liu Q, Salaverria I, Pittaluga S, et al. Follicular lymphomas in children and young adults: a comparison of the pediatric variant with usual follicular lymphoma. Am J Surg Pathol. 2013; 37: 333-343.

[8] Koo M, Ohgami RS. Pediatric-type Follicular Lymphoma and Pediatric Nodal Marginal Zone Lymphoma. Adv Anat Pathol. 2017; 24: 128-135.

[9] Lorsbach RB, Shay-Seymore D, Moore J, et al. Clinicopathologic analysis of follicular lymphoma occurring in children. Blood 2002; 99: 1959-1964.

[10] Ozawa MG, Bhaduri A, Chisholm KM, et al. A study of the mutational landscape of pediatric-type follicular lymphoma and pediatric nodal marginal zone lymphoma. Mod Pathol. 2016; 29: $1212-1220$.

[11] Louissaint A, Schafernak KT, Geyer J, et al. Pediatric-type nodal follicular lymphoma: a biologically distinct lymphoma with frequent MAPK pathway mutations. Blood 2016; 128: 1093-1100.

[12] Schmidt J, Gong S, Marafioti T, et al. Genome-wide analysis of pediatric-type follicular lymphoma reveals low genetic complexity and recurrent alterations of TNFRSF14 gene. Blood 2016; 128: 1101-1111.

[13] Launay E, Pangault C, Bertrand P, et al. High rate of TNFRSF14 gene alterations related to $1 \mathrm{p} 36$ region in de novo follicular lymphoma and impact on prognosis. Leukemia 2012; 26: 559-562.

[14] Attarbaschi A, Beishuizen A, Mann G, et al. Children and adolescents with follicular lymphoma have an excellent prognosis with either limited chemotherapy or with a 'watch and wait' strategy after complete resection. Ann Hematol. 2013; 92: 1537-1541.

[15] Zinzani PL. The many faces of marginal zone lymphoma. Hematology Am Soc Hematol Educ Progr. 2012; 1: 426-432.

[16] Elenitoba-Johnson KSJ, Kumar S, Lim MS, et al. Marginal zone B-cell lymphoma with monocytoid B-cell lymphocytes in pediatric patients without immunodeficiency: A report of two cases. Am J Clin Pathol. 1997; 107: 92-98.

[17] van den Brand M, van Krieken JH. Recognizing nodal marginal zone lymphoma: recent advances and pitfalls. A systematic review. Haematologica 2013; 98: 1003-1013.

[18] Salama ME, Lossos IS, Warnke RA, et al. Immunoarchitectural patterns in nodal marginal zone B-cell lymphoma: A study of 51 cases. Am J Clin Pathol. 2009; 132: 39-49. 
[19] Taddesse-Heath L, Pittaluga S, Sorbara L, et al. Marginal Zone B-Cell Lymphoma in Children and Young Adults. Am J Surg Pathol. 2003; 27: 522-531.

[20] Arcaini L, Lucioni M, Boveri E, et al. Nodal marginal zone lymphoma: Current knowledge and future directions of an heterogeneous disease. Eur J Haematol. 2009; 83: 165-174.

[21] Rizzo KA, Streubel B, Pittaluaga S, et al. Marginal zone lymphomas in children and the young adult population; Characterization of genetic aberrations by FISH and RT-PCR. Mod Pathol. 2010; 23: 866-873.

[22] Attygalle AD, Liu H, Shirali S, et al. Atypical marginal zone hyperplasia of mucosa-associated lymphoid tissue: a reactive condition of childhood showing immunoglobulin lambda light-chain restriction. Blood 2004; 104: 3343-3348.

[23] Kluin PM, Langerak AW, Beverdam-Vincent J, et al. Paediatric nodal marginal zone B-cell lymphadenopathy of the neck: a Haemophilus influenzae-driven immune disorder? 2015; 3: 302-314.
[24] Shaikh F, Ngan B-Y, Alexander S, et al. Progressive Transformation of Germinal Centers in Children and Adolescents: An Intriguing Cause of Lymphadenopathy. Pediatr Blood Cancer. 2013; 60: 26-30.

[25] Ferry JA, de Leval L, Louissant A Jr, et al. Follicular lymphoma. In: Jaffe ES, Arber DA, Campo E, Harris NL, Quintanella-Martinez L, eds. Hematopathology, 2nd ed. Philadelpha, PA: Saunders; 2017: 37: 321-352.

[26] Hartmann S, Winkelmann R, Metcalf R, et al. Immunoarchitectural patterns of progressive transformation of germinal centers with and without nodular lymphocyte-predominant Hodgkin lymphoma. Hum Pathol. 2015; 46: 1655-1661.

[27] Atra A, Meller S, Stevens R, et al. Conservative management of follicular non-Hodgkin's lymphoma in childhood. Br J Haematol. 1998; 103: 220-223.

A cikk a Creative Commons Attribution 4.0 International License (https://creativecommons.org/licenses/by/4.0/) feltételei szerint publikált Open Access közlemény, melynek szellemében a cikk bármilyen médiumban szabadon felhasználható, megosztható és újraközölhető, feltéve, hogy az eredeti szerző és a közlés helye, illetve a CC License linkje és az esetlegesen végrehajtott módosítások feltüntetésre kerülnek. (SID_1) 